\title{
Studi Pembuatan DTM Menggunakan Metode Slope Based Filtering dan Grid Based Filtering (Studi Kasus: Kelurahan Wonokromo Dan Lontar, Kota Surabaya)
}

\author{
Study Of DTM Determination Using Slope Based Filtering And Grid Based Filtering \\ (Case Study: Wonokromo And Lontar Sub-District, Surabaya) \\ Mahardi Wirantiko ${ }^{1}$, Hepi H. Handayani*2, Agung B. Cahyono ${ }^{3}$ \\ ${ }^{1,2,3}$ Departemen Teknik Geomatika, FTSLK-ITS, Kampus ITS Sukolilo, Surabaya, 60111, Indonesia \\ *Korespondensi penulis: Hapsari@geodesy.its.ac.id
}

Diterima: 14082020; Diperbaiki: 22082020; Disetujui: 25082020; Dipublikasi: 29112020

\begin{abstract}
Abstrak: Digital Terrain Model (DTM) merupakan model medan digital yang memuat informasi ketinggian permukaan tanah (bare earth surface) tanpa terpengaruh oleh vegetasi atau fitur buatan manusia lainnya, sedangkan Digital Surface Model (DSM) merupakan representasi permukaan bumi yang memuat lebih banyak informasi ketinggian termasuk semua objek yang berada di atas permukaan bumi seperti vegetasi, gedung, dan fitur lainnya. Perlu dilakukan percepatan dalam penyediaan informasi geospasial, dalam hal ini DTM sebagai unsur pembentuk peta topografi skala besar. Untuk itu diperlukan metode pembentukan DTM yang lebih efektif. Sehingga tujuan pada penelitian ini adalah mengkaji metode yang dapat menghasilkan DTM secara otomatis dan menghasilkan DTM turunan yang mendekati akurat. Pada penelitian ini metode yang digunakan untuk dikaji yaitu Slope Based Filtering (SBF) atau metode penyaringan berbasis lereng dan Grid Based Filtering (GBF) atau Metode Penyaringan Berbasis Grid. Terdapat dua daerah yang diteliti. Pada area pertama yaitu lokasi yang memiliki karakteristik daerah padat penduduk sehingga terdapat banyak bangunan yang saling berhimpit, area tersebut berlokasi di Kelurahan Wonokromo, Surabaya Selatan. Pada area kedua yaitu lokasi yang memiliki karakteristik terbuka, sedikit pemukiman dan banyak medan datar dan kosong, area tersebut berlokasi di Kelurahan Lontar, Surabaya Barat. Hasil data dari kedua metode tersebut kemudian dibandingkan terhadap DTM Stereoplotting yang digunakan sebagai referensi. Perbandingan tersebut berupa geomorfologi atau visualisasi, dan ketelitian geometri vertikal. Hasil dari penelitian ini menunjukkan metode Slope Based Filtering memiliki keakuratan yang lebih tinggi dibandingkan dengan Grid Based Filtering. Hal tersebut dibuktikan oleh hasil klasifikasi pengolahan data menggunakan delapan parameter pada masing-masing metode. Rata-rata RMS Error yang diperoleh di Wonokromo lebih kecil yaitu 0,605 meter dibandingkan dengan Kelurahan Lontar sebesar 1,605 m. Kelurahan Wonokromo memiliki rata-rata skala ketelitian peta 1: 2.500 sedangkan Kelurahan Lontar memiliki rata-rata kelas ketelitian peta 1: 5.000. Secara visual geomorfologi yang dihasilkan dari metode SBF lebih halus dibandingkan dengan GBF yang masih kasar.
\end{abstract}

Copyright $(2020$ Geoid. All rights reserved.

\begin{abstract}
Digital Terrain Model (DTM) is a digital terrain model that only contains ground level information (bare earth surface) without being affected by vegetation or other man-made features. While Digital Surface Model (DSM) is a representation of the earth's surface that contains more height information including all objects that are located on the surface of the earth such as vegetation, buildings, and other features. It is necessary to accelerate the provision of geospatial information, in this case DTM as an element of forming large-scale topographic maps. For this reason, a more effective DTM formation method is needed. The study was conducted to examine methods that can produce DTM automatically, in order to obtain a fast and efficient mapping method. In this study the method used are Slope Based Filtering (SBF) and Grid Based Filtering (GBF) method. Those approaches are applied in two different characteristics of study area. In the first area, which is a location that has characteristics of densely populated areas so that there are many buildings that coincide with each other, the area is located in Wonokromo Sub-District, South Surabaya. The second area has characteristics of open space with few settlements and a lot of barelands. The area is located in Lontar Village, West Surabaya. The results of the data processing based on two methods are then compared to the Stereoplotting DTM used as a reference. The comparison is performed as geomorphology analysis or visualization, and vertical geometry accuracy. The results of this study indicate that SBF method has a higher accuracy compared to the one of GBF. This is revealed by the results of the classification of data processing using eight parameters in each method. The average of RMS Error obtained in Wonokromo is smaller that is 0.605 meters compared to Lontar Village of $1.605 \mathrm{~m}$. Wonokromo has an average map accuracy scale of 1: 2,500 while Lontar which has an average map accuracy class of 1: 5,000. Visually, the geomorphology produced from the SBF method is finer than the GBF which is still rough.
\end{abstract}


Kata kunci: Digital Surface Model; Digital Terrain Model; Slope Based Filtering; Grid Based Filtering; Digital Surface Model

\section{Pendahuluan}

Kebutuhan akan data spasial detail dengan skala besar semakin meningkat, namun ketersediaan peta dasar yang ada belum dapat mengimbangi kebutuhan tersebut. Peta dasar yang telah dibuat di Indonesia pada umumnya adalah skala 1:50.000 dan beberapa kawasan Indonesia dengan skala 1:25.000. Peta RBI skala 1:10.000 dan 1:5.000 masih sangat terbatas pada daerah-daerah tertentu. Sedangkan kebutuhan akan peta dasar skala besar sangat diperlukan untuk percepatan pembangunan. Peta topografi merupakan peta dasar yang dibutuhkan untuk keperluan analisis geospasial. Peta dasar ini diperlukan untuk penyusunan Rencana Detail Tata Ruang (RDTR). Selain itu peta topografi diperlukan dalam bidang pemetaan kawasan rawan bencana, perencanaan dan analisis pertanian, perkebunan, dan pertambangan, serta pemetaan geologi detail (Martiana, dkk, 2017).

Salah satu unsur yang diperlukan pada pembuatan peta topografi adalah kontur. Pembuatan kontur detail umumnya diperoleh dengan melakukan pemetaan secara teristrial, serta dengan metode konvensional yaitu mengekstraksi data Digital Terrain Model (DTM) hasil manual stereoplotting. Pengerjaan dengan metode ini menghasilkan tingkat keakuratan yang tinggi, namun memerlukan waktu yang relatif lama sehingga belum bisa memenuhi permintaan informasi geospasial skala besar yang terus bertambah. Perencanaan tata wilayah kota yang baik didapatkan dari parameter waktu yang singkat dan hasil yang optimal dalam pembuatan rencana tata ruang kota (Martiana, dkk, 2017).

DTM merupakan model medan digital yang hanya memuat informasi ketinggian permukaan tanah (bare earth surface) tanpa terpengaruh oleh vegetasi atau fitur buatan manusia lainnya, sedangkan DSM merupakan representasi permukaan bumi yang memuat lebih banyak informasi ketinggian termasuk semua objek yang berada di atas permukaan bumi seperti vegetasi, gedung, dan fitur lainnya. Perlu dilakukan upaya percepatan dalam penyediaan informasi geospasial, dalam hal ini DTM sebagai unsur pembentuk peta topografi skala besar. Untuk itu diperlukan metode pembentukan DTM yang lebih efektif. Penelitian dilakukan untuk mengkaji metode yang dapat menghasilkan DTM dengan cara otomatis, agar diperoleh metode pemetaan yang cepat dan efisien (Jensen, 2007).

Pada penelitian sebelumnya (Pambudi, 2015) dilakukan perbandingan metode Slope Based Filtering dan Simple Morphological Filtering dan (Martiana dkk, 2017) dalam melakukan perbandingan SBF dengan Algoritma Macro TerraSolid dalam menghasilkan DTM secara otomatis yang menunjukkan metode tersebut dapat digunakan untuk metode alternatif dalam penyediaan DTM yang relatif lebih cepat dengan DTM Stereoplotting sebagai benchmarknya namun belum ada yang menunjukkan kemiripan yang mendekati dengan DTM Stereoplotting.

Berdasarkan faktor yang telah disebutkan diatas, pada penelitian ini akan dilakukan analisis ketelitian hasil DTM metode Slope Based Filtering (SBF) dan Grid Based Filtering (GBF) dalam menghasilkan dari data DSM terhadap DTM Stereoplotting sebagai referensi. Selain itu akan dikaji hasil visualisasi dari kedua metode tersebut.

\section{Data dan Metode}

Lokasi penelitian pada penelitian ini dibagi menjadi 2 (dua) area yang memiliki karakteristik berbeda. Area pertama adalah kawasan Kelurahan Wonokromo yang memiliki karakteristik wilayah padat penduduk, sehingga terdapat banyak bangunan yang berhimpit. Kelurahan tersebut terdapat pada NLP (Nomor Lembar Peta) pada DSM dan DTM 1608-4146 CE,CJ,CI, dan CD. Area kedua adalah kawasan Kelurahan Lontar yang memiliki karakteristik wilayah kawasan lahan terbuka, sehingga sedikit atau jarang ditemui bangunan maupun pemukiman. Kawasan tersebut terdapat pada NLP (Nomor Lembar Peta) pada DSM dan DTM sebagai berikut 1608-4148 AL,AQ,AK, dan AP. 


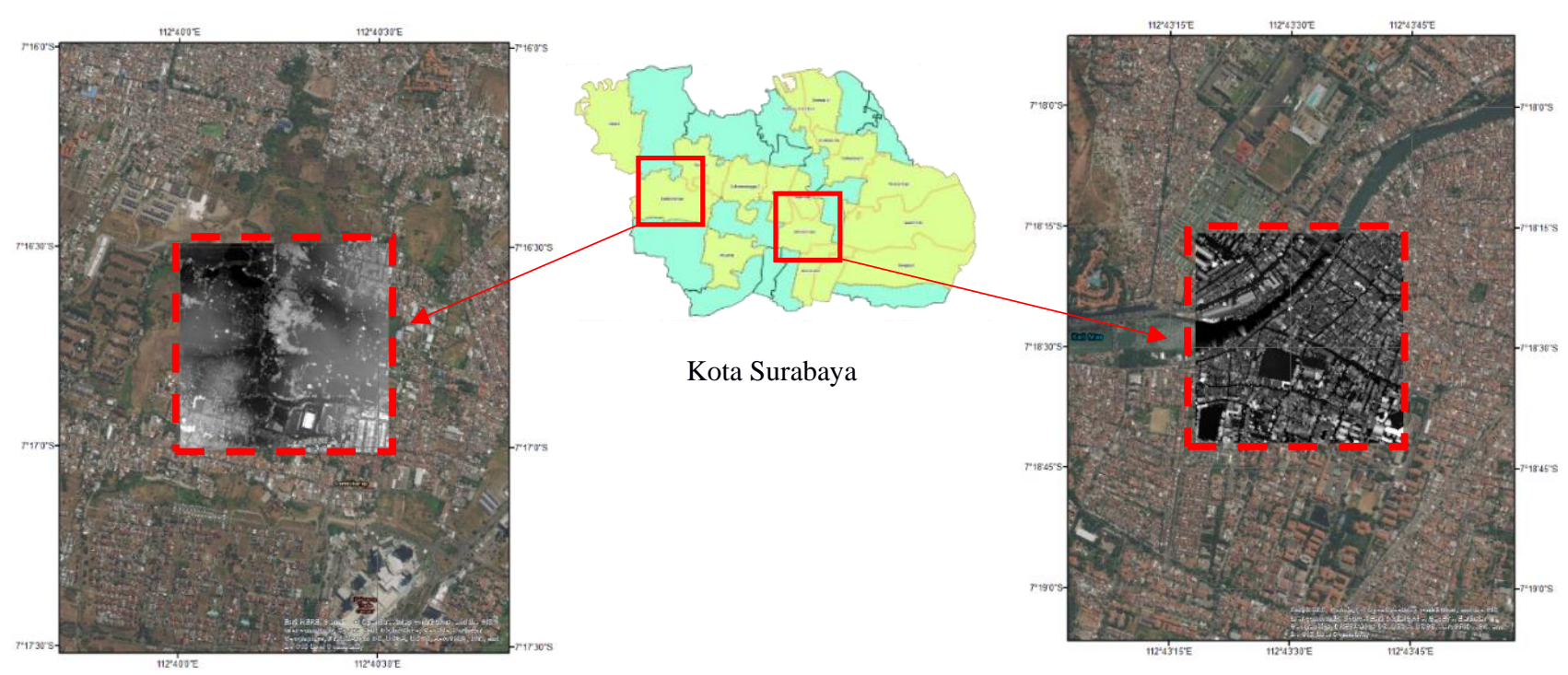

Gambar 1. Studi Lokasi Penelitian (Pengarang, 2020)

Data primer yang digunakan DSM LiDAR kawasan Kelurahan Wonokromo dan Kelurahan Lontar, Kota Surabaya yang didapatkan dari Dinas Cipta Karya dan Tata Ruang Pemerintah Kota Surabaya dengan resolusi spasial $25 \mathrm{~cm}$, dalam format *.bil (raster), DTM Stereoplotting kawasan Kelurahan Wonokromo dan Kelurahan Lontar yang digunakan sebagai data yang dianggap benar (referensi) dengan resolusi spasial $40 \mathrm{~cm}$ dalam format *.bil (raster), Data foto udara kawasan kelurahan Wonokromo dan Lontar, Kota Surabaya yang didapatkan dari Dinas Cipta Karya dan Tata Ruang Pemerintah Kota Surabaya dengan resolusi spasial 0,08 meter dalam format *.bil (raster).

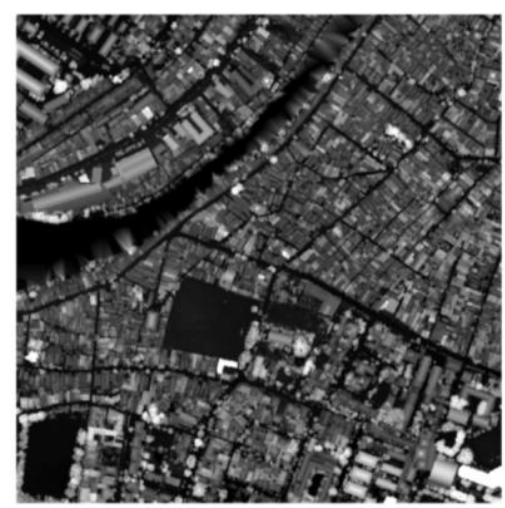

(a)

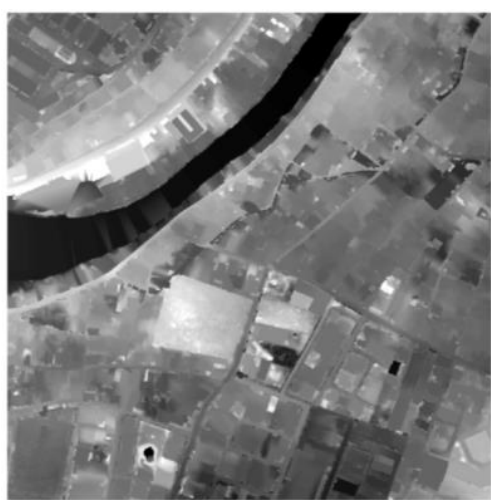

(b)

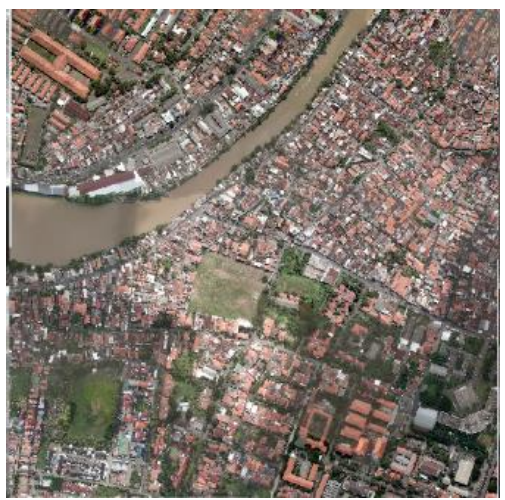

(c)

Gambar 2. DSM (a) DTM Stereoplotting (b) Orthophoto (c) Titik Training (Pengarang, 2020)

Gambar 3 menunjukkan seluruh metode yang diaplikasikan dalam penelitian perbandingan DTM hasil SBF dan GBF terhadap DTM Stereoplotting. Tahapan paling awal dilakukan Pemotongan Scene DSM dan DTM karena terdapat perbedaan ukuran luasan piksel yang terdapat dalam data DSM dan DTM Stereoplotting. Oleh karena itu, dilakukan pemotongan agar jumlah titik yang akan dijadikan perbandingan antara kedua data tersebut sama banyak dan memiliki pasangan titik perbandingan masing-masing. Setelah didapatkan jumlah luasan piksel yang sama dari data DSM, DTM, dan Orthophoto, lalu dilakukan pengklasifikasian objek-objek kedalam dua kelas, yaitu ground dan non ground berdasarkan analisa manual pada Orthophoto kedua wilayah. Selanjutnya hasil dari kelas ground adalah data yang digunakan untuk tahap filtering. Tujuan dari tahap ini yaitu mereduksi kesalahan dari fitur-fitur selain ground yang terkandung dari data DSM seperti bangunan dan vegetasi. 


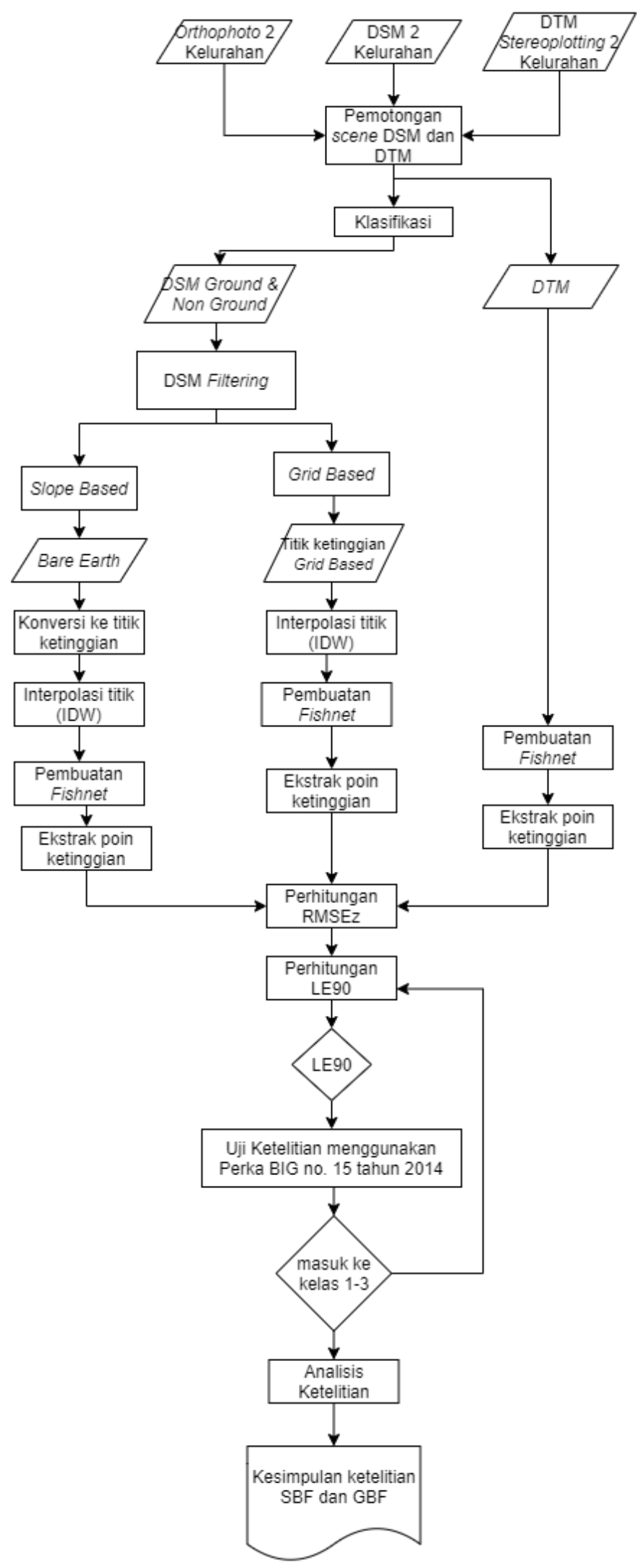

Gambar 3. Metode yang diaplikasikan dalam penelitian perbandingan DTM hasil SBF dan GBF terhadap DTM Stereoplotting 
Tahap kedua dalam pengolahan data, setelah data DSM dan DTM memiliki luasan piksel yang sama, dilakukan Slope Based Filtering untuk menyaring fitur non-ground di aplikasi SAGA GIS versi 7.6.1. pada tahap ini, dilakukan filtering menggunakan 8 parameter radius yang berbeda. Pada daerah Wonokromo (padat penduduk) digunakan radius 10, 30, 45, 60, 75, 90, 105 dan 120 (piksel). Sedangkan pada daerah Lontar (lahan terbuka) menggunakan radius 10, 20, 40, 80, 120, 160, 200, dan juga 240 (piksel). Kemudian parameter yang digunakan selanjutnya adalah approx. terrain slope sebesar $1^{\circ}$. Pada proses Grid Based Filtering, parameter yang digunakan di Wonokromo yaitu 4, 12, 18, 24, 30, 36, 42, 48 meter. Sedangkan pada Kelurahan Lontar yaitu 4, $8,16,32,48,64,80$, dan 96 meter. Inisiasi pemilihan besarnya radius ini berdasarkan karakteristik dan ukuran piksel yang terdapat pada masing-masing daerah yang mengacu pada ukuran piksel data DTM Stereoplotting yaitu 0,4 meter, maka radius dan grid yang dijadikan parameter pertama adalah 10x dari resolusi tersebut yaitu grid 4 meter dan radius 10 piksel.

Pada metode Grid Based Filtering, parameter luasan grid dibuat dalam 8 ukuran yang berbeda dalam masingmasing dua kelurahan. Setelah SBF dilakukan, tahap tersebut memisahkan 2 komponen data yang terdapat dalam DSM, yaitu Bare Earth (nilai yang dianggap sebagai ground) dan Removed Objects atau objek-objek selain dataran yang telah terbuang. Kemudian dari data Bare earth tersebut disimpan dalam format *GeoTiff yang kemudian dijadikan data vektor berupa titik-titik yang terbentuk dari Bare earth. Proses konversi pada aplikasi ArcGIS menggunakan tools Raster to Point. Setelah titik-titik tersebut didapatkan, maka dilakukan tahap interpolasi menggunakan metode Inverse Distance Weight (IDW). Metode ini dipilih karena dalam mengestimasi titik yang hilang tersebut dipengaruhi titik terdekat yang diketahui dibandingkan titik yang lebih jauh. Tujuan dari tahapan ini adalah untuk mengetahui ketinggian dari data ground yang telah hilang pada tahap filtering dikarenakan terdapat unsur non-ground diatasnya.

Setelah dilakukan interpolasi dan menghasilkan data raster mengenai ketinggian, pada metode SBF dilakukan pembuatan grid yang ukurannya mengikuti dari parameter ukuran dari GBF. Pendefinisiannya adalah dalam grid awal yang dibuat yaitu $4 \times 4$ meter, terdapat 1 titik rata-rata yang mewakilkan 10 piksel dari kedua data DSM dan DTM. Pada proses GBF, resampling titik dibuat fishnet yang berukuran sama dengan ukuran grid yang diproses. Hal ini dilakukan untuk mempertahankan resolusi dari kedua data yang akan dibandingkan. Pada tahap pembuatan fishnet ini bertujuan untuk menghasilkan titik-titik ketinggian DSM dan DTM yang jumlahnya sama agar memudahkan dalam proses perbandingan ketinggian setelahnya. Pada data DTM stereoplotting juga dilakukan tahap ini agar diketahui data ketinggian yang berbeda dalam satu koordinat.

Dari hasil fishnet, didapatkan titik yang tersebar merata pada tiap sisi scene DSM dan DTM. Pada titik titik tersebut kemudian dilakukan ekstrak titik ketinggian yang didasarkan dari data raster DSM hasil interpolasi dan juga data DTM referensi. Kemudian selisih ketinggian dari dua data tersebut digunakan dalam perhitungan RMS Error z. Setelah selisih dari ketinggian DSM hasil SBF dan GBF, kemudian dihitung RMS Error untuk ketinggian $(R M S E z)$. Pada tahap analisis ini dilakukan perbandingan data ketinggian DTM hasil pengolahan masing-masing metode dengan poin-poin ketinggian DTM hasil stereoplotting (referensi) menggunakan RMS error pada hasil dari metode SBF. Ketinggian DTM referensi dianggap sebagai nilai yang benar, karena metode Stereoplotting merupakan teknik yang dianggap akurat bare earth nya (ketinggian diatas permukaan tanah), sedangkan selisih ketinggian antara DTM hasil filtering dan DTM stereoplotting merupakan nilai error. Dari data RMSEz yang telah didapat, lalu dihitung LE90 nya. untuk mendapatkan akurasi vertikal didapatkan dari perhitungan ketelitian geometrik vertikal (ketinggian) yang didefinisikan sebagai nilai jarak yang menunjukkan bahwa 90\% kesalahan atau perbedaan nilai ketinggian objek di peta dengan nilai ketinggian sebenarnya tidak lebih besar daripada nilai jarak tersebut yang dinamakan perhitungan Linear Error 90\% (LE90).

Uji ketelitian menggunakan PERKA BIG. No 15 tahum 2014 data LE90 yang telah didapat, dari 3 parameter radius untuk SBF dan 3 parameter ukuran grid pada GBF, kemudian diklasifikasikan kedalam tabel yang mengacu pada Peraturan Badan Informasi Geospasial Nomor 6 Tahun 2018 tentang Perubahan Atas Peraturan Kepala Badan Informasi Geospasial Nomor 15 Tahun 2014 Tentang Pedoman Teknis Ketelitian Peta Dasar. Pada tahap sebelumnya, didapatkan hasil klasifikasi ketelitian peta dasar, kedalam skala dan kelas. Dari data 
tersebut kemudian dianalisis bagaimana dalam radius pada SBF dan grid pada GBF karakteristik medan daerah yang berbeda dapat mempengaruhi hasil ketelitian dari kedua metode tersebut.

\section{Hasil dan Pembahasan}

\section{Hasil Klasifikasi Ground \& Non Ground}
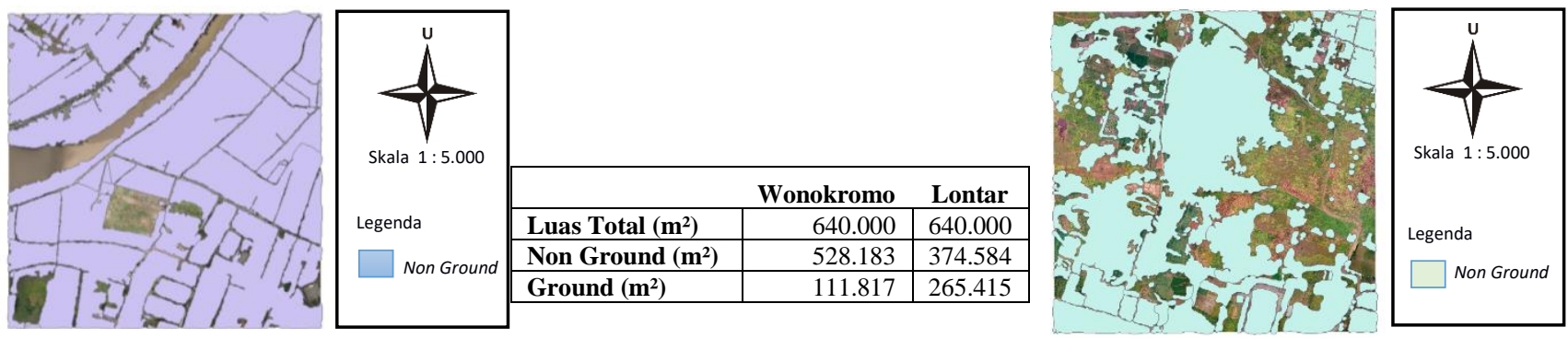

Gambar 4. Hasil Klasifikasi Ground \& Non Ground

Pada tabel diatas didapatkan luas area non ground lebih besar dibandingkan dengan ground dikarenakan pada daerah tersebut banyak dijumpai vegetasi seperti perkebunan dan pepohonan yang tinggi. Pada daerah tersebut juga terdapat pemukiman yang harus diklasifikasikan kedalam non ground berdasarkan data Orthhophoto di dua kelurahan. Perbandingan menunjukkan bahwa angka luasan fitur non ground antara Kelurahan Wonokromo dan Lontar menghasilkan Wonokromo jauh lebih banyak dibandingkan dengan Kelurahan Lontar. Hal ini pula menjelaskan bahwa penulis melakukan penelitian pada dua karakteristik wilayah yang berbeda.

\section{Hasil Filtering SBF dan GBF}

\section{a. Hasil Filtering SBF}

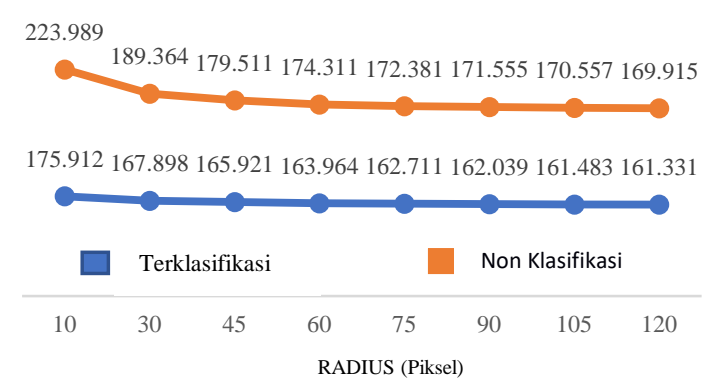

(a)

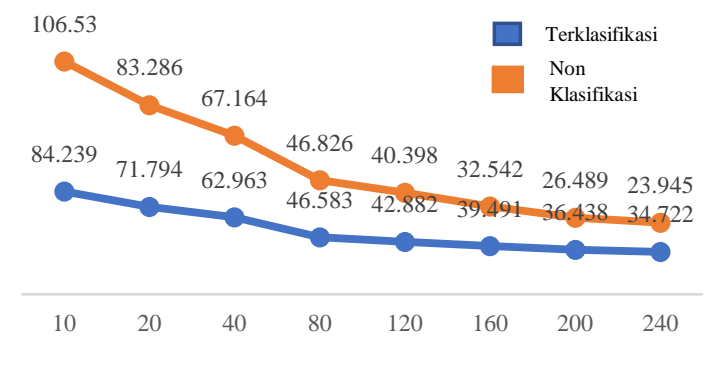

(b)

Gambar 5. Grafik Hasil Jumlah Titik Bare Earth Kelurahan Wonokromo (a) dan Lontar (b)

Dari hasil yang didapat diatas menunjukkan jumlah titik bare earth yang dibentuk pada 2 jenis data DSM di Kelurahan Wonokromo. Pada jenis data klasifikasi tentunya terdapat jumlah titik bare earth yang dihasilkan lebih sedikit dikarenakan piksel pada fitur non ground telah dihilangkan. Pada kedua jenis data menunjukkan rentang perbedaan jumlah titik bare earth yang dihasilkan antara radius 10 ke radius-radius setelahnya memiliki rentang yang jauh. Sedangkan pada radius 30 hingga 120 menghasilkan rentang perbedaan yang kecil. Hal ini dikarenakan konsep dari SBF ini sendiri adalah menghilangkan ketinggian dari dua cell yang berdekatan. Sehingga apabila pada radius tertentu menganggap antara dua cell tidak memiliki slope yang terjal, maka jumlah piksel yang dihilangkan juga semakin sedikit. Pada kelurahan padat penduduk tersebut, titik yang dianggap ground sebagai referensi jumlahnya sedikit, oleh karena itu dapat dilakukan dengan mengurangi parameter search radius yang digunakan. Berbeda dengan area terbuka (Lontar) yang memiliki rentang perbedaan hasil jumlah titik bare earth yang merata pada radius 10-80, selanjutnya pada radius 120-240 menunjukkan perbedaan yang lebih kecil. Pada kedua jenis data tersebut juga menunjukkan jenis data 
terklasifikasi memiliki jumlah titik yang lebih sedikit dikarenakan banyak piksel yang hilang di fitur non ground pada proses klasifikasi.

\section{b. Hasil Filtering GBF}

Tabel 1. Jumlah Titik GBF Wonokromo (a) dan Lontar (b)

(a)

\begin{tabular}{crr}
\hline $\begin{array}{c}\text { Ukuran } \\
\text { Grid (m) }\end{array}$ & $\begin{array}{c}\text { Jumlah titik grid } \\
\text { Terklasifikasi }\end{array}$ & $\begin{array}{c}\text { Jumlah titik grid } \\
\text { Non Klasifikasi }\end{array}$ \\
\hline 4 & 32.835 & 32.835 \\
12 & 4.422 & 4.422 \\
18 & 1.936 & 1.936 \\
24 & 1.089 & 1.089 \\
30 & 729 & 729 \\
36 & 484 & 484 \\
42 & 361 & 361 \\
48 & 289 & 289 \\
\hline
\end{tabular}

(b)

\begin{tabular}{crr}
\hline $\begin{array}{c}\text { Ukuran } \\
\text { Grid (m) }\end{array}$ & $\begin{array}{c}\text { Jumlah titik grid } \\
\text { Terklasifikasi }\end{array}$ & $\begin{array}{c}\text { Jumlah titik grid } \\
\text { Non Klasifikasi }\end{array}$ \\
\hline 4 & 32.835 & 32.835 \\
8 & 9.900 & 9.900 \\
16 & 2.500 & 2.500 \\
32 & 625 & 625 \\
48 & 272 & 272 \\
64 & 156 & 156 \\
80 & 100 & 100 \\
96 & 64 & 64 \\
\hline
\end{tabular}

Dari tabel diatas dapat dianalisis bahwa semakin besar ukuran grid yang digunakan, maka semakin sedikit titik yang terbentuk. Hal ini dikarenakan pada ukuran grid yang lebih besar, lebih banyak juga mengandung jumlah piksel yang banyak, jadi data piksel yang dibandingkan untuk menghasilkan satu titik terendah juga semakin banyak.

\section{Hasil Interpolasi, Gridding, dan Jumlah Resampling Titik}

Bare earth menghasilkan data ketinggian yang tidak lengkap, untuk menentukan titik-titik ketinggian yang hilang yang disebabkan proses SBF, dilakukan interpolasi titik untuk mengestimasi titik-titik yang hilang tersebut.

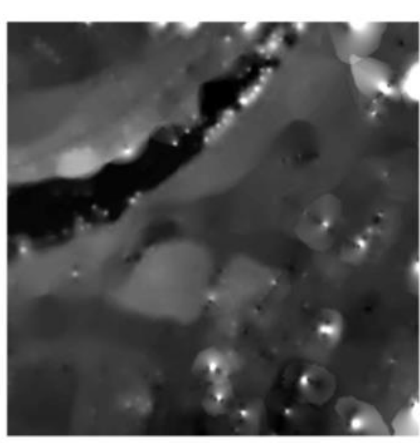

(a)
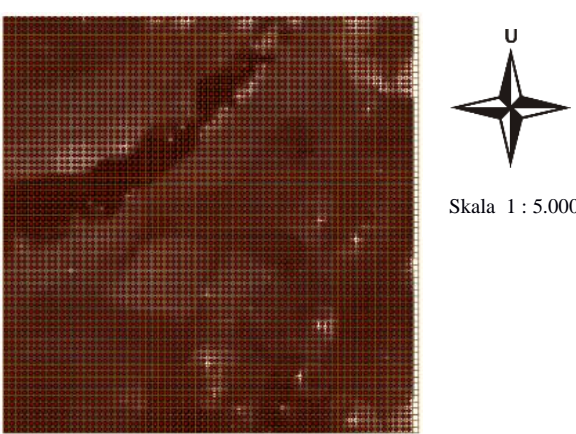

Skala $1: 5.000$

(b)

Gambar 6. Hasil Interpolasi (a) dan hasil fishnetting (b)

Perbandingan dilakukan antara data DTM hasil pengolahan dan data ketinggian dari DTM referensi. Akan tetapi permasalahan yang ditemukan adalah jumlah titik yang terbentuk antara DTM hasil SBF dan DTM referensi jumlahnya berbeda dan memiliki lokasi yang tidak sama. Untuk mengatasi hal tersebut, dilakukan pembentukan fishnet untuk menghasilkan resampling titik-titik grid dengan jumlah dan ukuran yang sama mengikuti dengan grid pada proses GBF. Pada gambar (a) merupakan hasil dari interpolasi IDW yang kemudian dilakukan sampling titik ketinggian menggunakan fishnet pada gambar (b). Bentuk dari hasil interpolasi berbeda mengikuti dari data bare earth yang terbentuk. Contoh dari hasil interpolasi diatas pada Kelurahan Wonokromo GBF grid $12 \mathrm{~m}$. 
Setelah fishnet terbentuk, maka dilakukan ekstrak poin-poin ketinggian sesuai dengan grid yang dibentuk. Berikut merupakan hasil dari jumlah titik-titik yang terbentuk:

(a)

\begin{tabular}{ccc}
\hline $\begin{array}{c}\text { Radius } \\
\text { (Piksel) }\end{array}$ & $\begin{array}{c}\text { Jumlah titik } \\
\text { Resampling } \\
\text { Wonokromo }\end{array}$ & $\begin{array}{c}\text { Jumlah titik } \\
\text { Resampling } \\
\text { Lontar }\end{array}$ \\
\hline 10 & 39.800 & 39.800 \\
30 & 9.900 & 9.900 \\
45 & 2.500 & 2.500 \\
60 & 625 & 625 \\
75 & 289 & 289 \\
90 & 156 & 156 \\
105 & 100 & 100 \\
120 & 64 & 64 \\
\hline
\end{tabular}

Tabel 2. Hasil Titik Resampling SBF (a) dan GBF (b)

(b)

\begin{tabular}{ccc}
\hline $\begin{array}{c}\text { Ukuran Grid } \\
(\mathbf{m})\end{array}$ & $\begin{array}{c}\text { Jumlah Titik } \\
\text { Resampling } \\
\text { Wonokromo }\end{array}$ & $\begin{array}{c}\text { Jumlah Titik } \\
\text { Resampling Lontar }\end{array}$ \\
\hline 4 & 32.835 & 32.835 \\
12 & 4.422 & 4.422 \\
18 & 1.936 & 1.936 \\
24 & 1.089 & 1.089 \\
30 & 729 & 729 \\
36 & 484 & 484 \\
42 & 361 & 361 \\
48 & 289 & 289 \\
\hline
\end{tabular}

\section{Hasil RMSEz, LE90, dan Klasifikasi ke Perka BIG no. 15 Tahun 2014}

\section{a. Slope Based Filtering}

Ketinggian DTM hasil pengolahan dengan DTM hasil stereoplotting (referensi) menggunakan RMS error pada hasil dari metode SBF. Ketinggian DTM referensi dianggap sebagai nilai yang benar, karena metode Stereoplotting merupakan teknik yang dianggap akurat bare earth nya (ketinggian diatas permukaan tanah), sedangkan selisih ketinggian antara DTM hasil filtering dan DTM stereoplotting merupakan nilai error.

Tabel 3. Hasil SBF Wonokromo Terklasifikasi (a) dan Non Klasifikasi (b)

\begin{tabular}{ccccc}
\hline $\begin{array}{c}\text { Radius } \\
\text { (Piksel) }\end{array}$ & $\begin{array}{c}\text { RMSEz } \\
(\mathbf{m})\end{array}$ & $\begin{array}{c}\text { LE90 } \\
(\mathbf{m})\end{array}$ & Skala & Kelas \\
\hline 10 & 0,435 & 0,718 & $1: 2.500$ & 2 \\
30 & 0,407 & 0,673 & $1: 2.500$ & 2 \\
45 & 0,399 & 0,659 & $1: 2.500$ & 2 \\
60 & 0,393 & 0,648 & $1: 2.500$ & 2 \\
75 & 0,385 & 0,635 & $1: 2.500$ & 2 \\
90 & 0,369 & 0,609 & $1: 2.500$ & 2 \\
105 & 0,389 & 0,642 & $1: 2.500$ & 2 \\
120 & 0,361 & 0,596 & $1: 2.500$ & 2 \\
\hline
\end{tabular}

\begin{tabular}{ccccc}
\hline \multicolumn{6}{c}{$(\mathrm{b})$} \\
$\begin{array}{c}\text { Radius } \\
\text { (Piksel) }\end{array}$ & $\begin{array}{c}\text { RMSEz } \\
(\mathbf{m})\end{array}$ & $\begin{array}{c}\text { LE90 } \\
(\mathbf{m})\end{array}$ & Skala & Kelas \\
\hline 10 & 1.586 & 2.618 & $1: 10.000$ & 2 \\
30 & 0.387 & 0.638 & $1: 2.500$ & 2 \\
45 & 0.332 & 0.549 & $1: 2.500$ & 2 \\
60 & 0.314 & 0.519 & $1: 2.500$ & 2 \\
75 & 0.325 & 0.537 & $1: 2.500$ & 2 \\
90 & 0.333 & 0.549 & $1: 2.500$ & 2 \\
105 & 0.343 & 0.566 & $1: 2.500$ & 2 \\
120 & 0,345 & 0,569 & $1: 2.500$ & 2 \\
\hline
\end{tabular}

Tabel diatas untuk Kelurahan Wonokromo Non Klasifikasi (b), dapat dilihat kelas ketelitian yang paling tinggi dihasilkan pada radius 60. Hal ini dikarenakan masih adanya fitur non ground yang direduksi dengan baik pada rentang $24 \times 24$ meter. Pada radius 10, ketelitian yang dihasilkan yaitu paling rendah hanya pada 1:10.000 dikarenakan hanya $4 \times 4$ meter rentang radius yang didapati untuk mereduksi fitur non ground yang mencapai 26 meter. Pada hasil analisis tersebut juga dapat disimpulkan bahwa penggunaan metode SBF pada Kelurahan Wonokromo baik pada jenis data terklasifikasi dan non klasifikasi dapat dibuat peta dengan skala mencapai 1 : 2.500 dengan interval kontur 1 meter.

Dari Tabel 4, hasil filtering menggunakan SBF di Kelurahan Lontar, radius dan ukuran grid paling teliti adalah pada radius 10 pada jenis data Terklasifikasi dan radius 40 di jenis data Non Klasifikasi. Sedangkan pada radius 240 pada Non klasifikasi dan Klasifikasi menghasilkan data kelas ketelitian yang paling tidak teliti. 
Tabel 4. Hasil SBF Lontar Terklasifikasi (a) dan Non Klasifikasi (b)

(a)

\begin{tabular}{ccccc}
\hline $\begin{array}{c}\text { Radius } \\
\text { (Piksel) }\end{array}$ & $\begin{array}{c}\text { RMSEz } \\
(\mathbf{m})\end{array}$ & $\begin{array}{c}\text { LE90 } \\
(\mathbf{m})\end{array}$ & Skala & Kelas \\
\hline 10 & 0,832 & 1,373 & $1: 5.000$ & 2 \\
20 & 0,929 & 1,532 & $1: 5.000$ & 3 \\
40 & 1,039 & 1,715 & $1: 5.000$ & 3 \\
80 & 1,672 & 2,759 & $1: 10.000$ & 2 \\
120 & 1,638 & 2,703 & $1: 10.000$ & 2 \\
160 & 2,16 & 3,564 & $1: 10.000$ & 3 \\
200 & 2,225 & 3,671 & $1: 10.000$ & 3 \\
240 & 2,27 & 3,907 & $1: 10.000$ & 3 \\
\hline
\end{tabular}

(b)

\begin{tabular}{ccccc}
\hline $\begin{array}{c}\text { Radius } \\
\text { (Piksel) }\end{array}$ & $\begin{array}{c}\text { RMSEz } \\
(\mathbf{m})\end{array}$ & $\begin{array}{c}\text { LE90 } \\
(\mathbf{m})\end{array}$ & Skala & Kelas \\
\hline 10 & 1,397 & 2,306 & $1: 10.000$ & 2 \\
20 & 1,066 & 1,76 & $1: 5.000$ & 3 \\
40 & 0,862 & 1,422 & $1: 5.000$ & 2 \\
80 & 1,438 & 2,373 & $1: 10.000$ & 2 \\
120 & 1,943 & 3,207 & $1: 10.000$ & 3 \\
160 & 1,014 & 1,6733 & $1: 5.000$ & 3 \\
200 & 2,461 & 4,061 & $1: 25.000$ & 1 \\
240 & 2,74 & 4,521 & $1: 25.000$ & 1 \\
\hline
\end{tabular}

\section{b. Grid Based Filtering}

Tabel 5. Hasil GBF Wonokromo Terklasifikasi (a) dan Non Klasifikasi (b)

(a)

\begin{tabular}{ccccc}
\hline $\begin{array}{c}\text { Ukuran } \\
\text { Grid } \\
(\mathbf{m})\end{array}$ & $\begin{array}{c}\text { RMSEz } \\
(\mathbf{m})\end{array}$ & $\begin{array}{c}\text { LE90 } \\
(\mathbf{m})\end{array}$ & Skala & Kelas \\
\hline 4 & 1,2005 & 1,98 & $1: 5.000$ & 1 \\
12 & 0,62 & 1,023 & $1: 5.000$ & 1 \\
18 & 0,48 & 0,792 & $1: 2.500$ & 3 \\
24 & 0,372 & 0,614 & $1: 2.500$ & 2 \\
30 & 0,35 & 0,578 & $1: 2.500$ & 2 \\
36 & 0,306 & 0,505 & $1: 2.500$ & 2 \\
42 & 0,302 & 0,499 & $1: 2.500$ & 1 \\
48 & 0,283 & 0,466 & $1: 2.500$ & 1 \\
\hline
\end{tabular}

(b)

\begin{tabular}{ccccc}
\hline $\begin{array}{c}\text { Ukuran Grid } \\
(\mathbf{m})\end{array}$ & $\begin{array}{c}\text { RMSEz } \\
(\mathbf{m})\end{array}$ & $\begin{array}{c}\text { LE90 } \\
(\mathbf{m})\end{array}$ & Skala & Kelas \\
\hline 4 & 2,986 & 4,928 & $1: 25.000$ & 1 \\
12 & 0,894 & 1,475 & $1: 5.000$ & 2 \\
18 & 0,457 & 0,755 & $1: 2.500$ & 3 \\
24 & 0,285 & 0,471 & $1: 2.500$ & 1 \\
30 & 0,255 & 0,421 & $1: 2.500$ & 1 \\
36 & 0,268 & 0,442 & $1: 2.500$ & 1 \\
42 & 0,268 & 0,442 & $1: 2.500$ & 1 \\
48 & 0,293 & 0,484 & $1: 2.500$ & 1 \\
\hline
\end{tabular}

Tabel 6. Hasil GBF Lontar Terklasifikasi (a) dan Non Klasifikasi (b)

(a)

\begin{tabular}{ccccc}
\hline $\begin{array}{c}\text { Ukuran } \\
\text { Grid } \\
(\mathbf{m})\end{array}$ & $\begin{array}{c}\text { RMSEz } \\
(\mathbf{m})\end{array}$ & $\begin{array}{c}\text { LE90 } \\
(\mathbf{m})\end{array}$ & Skala & Kelas \\
\hline 4 & 1,018 & 1,68 & $1: 2.500$ & 3 \\
8 & 0,899 & 1,483 & $1: 2.500$ & 2 \\
16 & 0,739 & 1,2 & $1: 2.500$ & 2 \\
32 & 0,753 & 1,242 & $1: 2.500$ & 2 \\
48 & 1,038 & 1,712 & $1: 2.500$ & 3 \\
64 & 1,287 & 2,124 & $1: 10.000$ & 2 \\
80 & 1,66 & 2,74 & $1: 10.000$ & 2 \\
96 & 1,798 & 2,967 & $1: 10.000$ & 3 \\
\hline
\end{tabular}

(b)

\begin{tabular}{ccccc}
\hline $\begin{array}{c}\text { Ukuran Grid } \\
(\mathbf{m})\end{array}$ & $\begin{array}{c}\text { RMSEz } \\
(\mathbf{m})\end{array}$ & $\begin{array}{c}\text { LE90 } \\
(\mathbf{m})\end{array}$ & Skala & Kelas \\
\hline 4 & 2,307 & 3,806 & $1: 10.000$ & 3 \\
8 & 1,449 & 2,391 & $1: 10.000$ & 2 \\
16 & 0,834 & 1,377 & $1: 5.000$ & 3 \\
32 & 0,573 & 0,945 & $1: 2.500$ & 3 \\
48 & 0,94 & 1,552 & $1: 5.000$ & 3 \\
64 & 1,265 & 2,088 & $1: 10.000$ & 2 \\
80 & 1,612 & 2,659 & $1: 10.000$ & 2 \\
96 & 2,066 & 3,41 & $1: 10.000$ & 3 \\
\hline
\end{tabular}

Dari tabel diatas, dapat dianalisis bahwa penggunaan grid yang terlalu kecil atau terlalu besar belum efektif pada wilayah yang memiliki karakterisitik wilayah terbuka. Namun pada analisisnya jika dibandingkan dengan Kelurahan Wonokromo yang pada hasil klasifikasinya memiliki titik ketinggian terbentuk merata, belum dapat menyamai hasil tersebut. Pada kelurahan Lontar pada jenis data terklasifikasi memiliki DSM yang banyak ditemukan data yang kosong di bagian tengah. Hal ini ditunjukkan pada Gambar 7. 


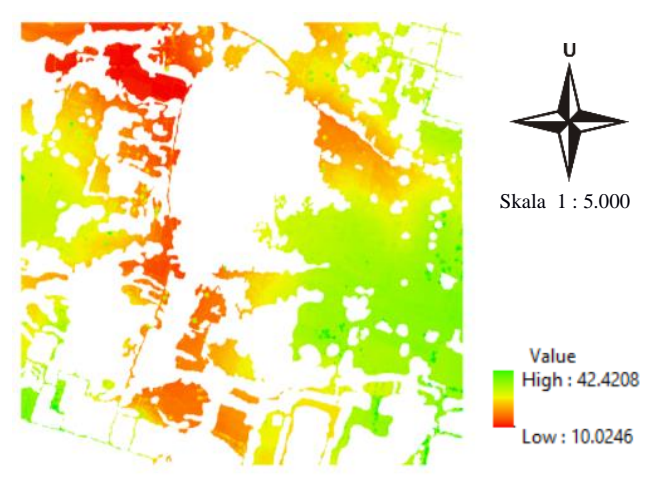

(a)

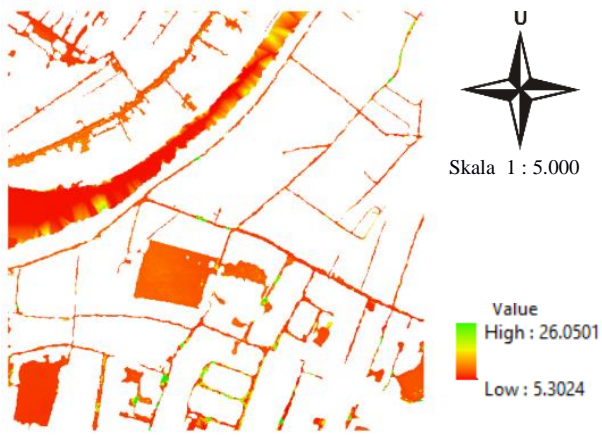

(b)

Gambar 7. Hasil Klasifikasi Ground \& Non Ground Lontar (a) dan Wonokromo (b)

Pada pembentukan ketinggian dari luasan data yang kosong tersebut menggunakan metode interpolasi. Pada proses perbandingan ketinggian dengan DTM Stereoplotting, data yang digunakan oleh setiap parameter dan jenis data adalah data hasil interpolasi. Pada kelurahan lontar, hasil ketinggian yang dibentuk dari interpolasi memiliki rentang yang jauh hingga 3 meter. Hal ini disebabkan karena dalam mengestimasi titik ketinggian menggunakan pertimbangan titik disekitarnya yang jaraknya sangat jauh. Hal sebaliknya terjadi pada Kelurahan Wonokromo yang membentuk DSM terklasifikasi dan menghasilkan titik ketinggian yang merata dapat dilihat pada gambar (b) Pada proses interpolasi menghasilkan titik ketinggian terestimasi dari pertimbangan titik yang lokasinya tidak terlalu jauh. Sehingga pada perbandingan hasil DSM yang sudah tersaring dengan DTM Stereoplotting tidak terlalu jauh, nillai RMSEz yang dihasilkan juga lebih kecil dibandingkan dengan Kelurahan Lontar.

\section{Hasil Geomorfologi DTM SBF dan GBF dengan DTM Stereoplotting}
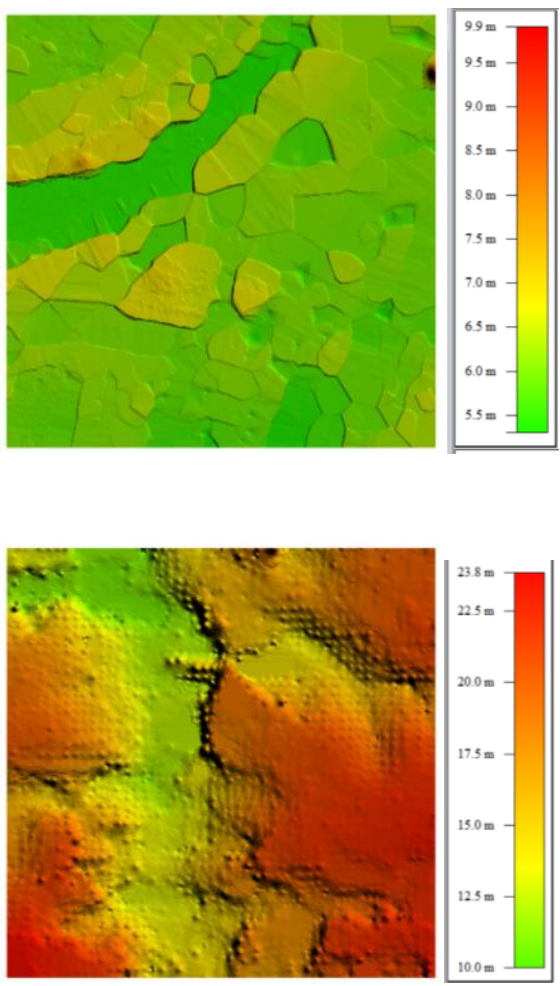
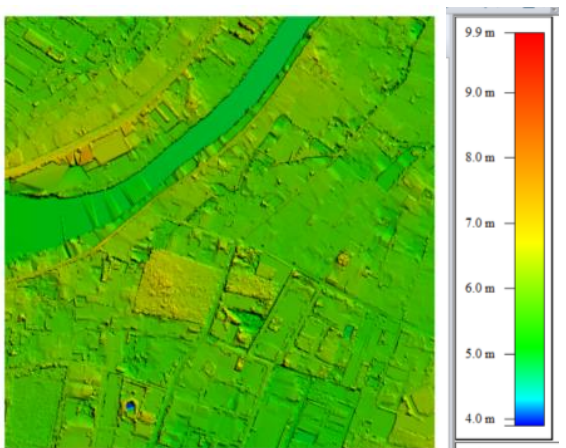

(a)

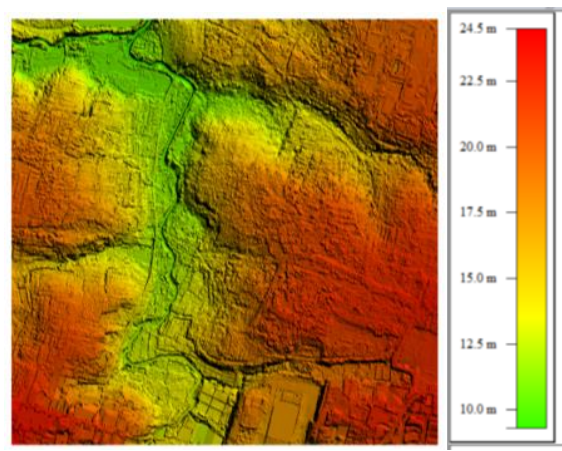

(b)

Gambar 8. Hasil Geomorfologi DTM SBF dan GBF dengan DTM Stereoplotting 
Hasil visualisasi yang didapatkan pada radius 60 terklasifikasi secara umum sudah menyerupai DTM stereoplotting. Pada radius tersebut permukaan yang terbentuk juga sudah halus. Hal ini dikarenakan pada radius tersebut banyak fitur non ground yang hilang dan tergantikan dengan ketinggian yang diestimasi dengan menggunakan metode interpolasi. Berberapa fitur-fitur yang terbentuk seperti jalan, sungai, dan datarandataran pada radius 60 Terklasifikasi juga sudah menyerupai DTM stereolotting.

Hasil visualisasi yang didapatkan pada ukuran grid 16 Terklasifikasi secara umum sudah menyerupai DTM stereoplotting. Hanya saja pada grid 16 Terklasifikasi permukaan yang dibentuk lebih kasar dan terlihat banyak fitur yang berbentuk membulat dibandingkan dengan DTM SBF. Hal ini dikarenakan pada grid tersebut menghasilkan satu titik dalam ukuran grid 16x16 meter, sehingga bentuk grid pada processing data di GBF masih terlihat. Beberapa fitur-fitur ground yang ketinggiannya dibawah sepuluh meter dibandingkan dengan DTM Stereoplotting sudah terbentuk.

\section{Kesimpulan}

Kesimpulan dari penelitian ini, perbandingan antara metode SBF dan GBF, metode yang paling akurat secara keseluruhan adalah SBF pada Kelurahan Wonokromo dengan ketelitian mencapai $1: 2.500$ pada kelas 1 . Metode SBF dan GBF dapat digunakan untuk menghasilkan peta dengan skala $1: 2.500$ pada Kelurahan Wonokromo dan Lontar pada ukuran grid 32×32 meter. Semakin besar radius yang digunakan dalam parameter SBF, maka semakin sedikit bare earth yang dibentuk, semakin banyak objek-objek yang dihilangkan (Removed Objects). Sebaliknya, semakin kecil radius yang digunakan dalam parameter SBF, maka semakin banyak bare earth yang dibentuk, semakin sedikit objek-objek yang dihilangkan (Removed Objects). Berdasarkan hasil visual geomorfologi DTM yang terbentuk menggunakan metode SBF sudah menyerupai DTM Stereoplotting. Unsur-unsur yang terbentuk seperti sungai juga sudah menyerupai DTM stereoplotting yang digunakan sebagai referensi.

\section{Ucapan Terimakasih}

Ucapan terimakasih penulis sampaikan kepada Dinas Cipta Karya dan Tata Kota Kota Surabaya yang telah memberikan dukungan pada penelitian ini berupa data DSM dan data DTM Stereoplotting.

\section{Daftar Pustaka}

Badan Informasi Geospasial. (2018). Peraturan Kepala Badan Informasi Geospasial Nomor 6 Tahun 2018: Perubahan Atas Peraturan Kepala Badan Informasi Geospasial Nomor 15 tahun 2014 Tentang Pedoman Teknis Ketelitian Peta Dasar

Jensen, J. R. (2007). Remote Sensing of the Environment: An earth resource perspective. 2ndPrentice-Hall series in Geographic Information Science, USA.

Martiana, D.N. Prasetyo Y. Wijaya, P.A. (2017). Analisis Akurasi DTM Terhadap Penggunaan Data Point Clouds dari Foto Udara dan LAS LiDAR Berbasis Metode Penapisan Slope Based Filtering dan Algoritma Macro TerraSolid. Yogyakarta: Program Teknik Geodesi Universitas Gadjah Mada.

Pambudi, L. C. (2015). Analisis Akurasi Penapisan DSM ke DTM Menggunakan Metode Simple Morphological Filter dan Slope Based Filtering. Semarang: Skripsi, Jurusan Teknik Geodesi, Fakultas Teknik Universitas Diponegoro.

Pfreifer, N. (2008). Digital surface model and digital terrain model filtering. Austria: Institute of Photogrammetry and Remote Sensing Vienna University of Technology.

Estoque, Ronald, Murayama Y, Tadono T, Thapa R. (2015). Measuring urban volume: geospatial technique and application. Tsukuba Geoenvironmental Sciences, Vol. 11, pp. 13-20, Dec. 25, 2015

Vosselman, G. (2000). Slope Based Filtering of Laser Altimetry Data. Belanda: Department of Geodesy, Faculty of Civil Engineering and Geosciences Delft University of Technology, The Amsterdam.

This article is licensed under a Creative Commons Attribution-ShareAlike 4.0 International License. 